Vera GUDAC DODIĆ, Ph. D.

\title{
STATE POLICY AND WOMAN'S IDENTITY IN SOCIALISM
}

\begin{abstract}
The paper focuses on the ways in which the state directed the processes of constructing female identities in socialism and exerted influence on the formulation of woman's social roles in Serbia and Yugoslavia. The text indicates attributes and gender roles based on the ideal image of a woman constructed in times of the early socialist state.
\end{abstract}

Key words: identity, roles, woman, ideal image, socialism

\section{Introduction}

The processes of creating women's identities, ${ }^{1}$ by the construction of the ideal image of a woman in socialist Serbia and Yugoslavia, were directed by state policy, permeated by the ideology of socialism and communism and partially dependant on the Communist Party's activities.

Up to World War II, women's behaviour and roles were deeply submerged into dominant patriarchy and traditionalism. Economic underdevelopment, as well as ubiquitous patriarchal ideology, shaped gender relations.

Rural environments and rural communities in Serbia were dominant, particularly in the first decades of the $20^{\text {th }}$ century, in contrast to towns which were developing at different pace. Complete dominance of village population (more than $80 \%$ ), small property and small parcel ownership characterized Serbia in that period. Such property structure prevailed not only in Serbia but also in Yugoslavia, where in 1931 , two thirds of the overall number of estates $(67.8 \%)$ were not bigger than five ha. ${ }^{2}$ The majority of people lived off ag-

1 Gender identity is "the social construct of culturally prescribed characteristics and behaviours. It is formed through the network of incentives and pressures by different economic, political and social forces". Isidora Jarić, "Sinhronicitet društvene promene i konstrukta rodnih uloga: Tradicionalizam i modernost kao sadržaji poželjnog modela ženskih rodnih uloga u ženskim časopisima u poslednjoj četvrtini 20. veka" ["Synchronicity of Social Change and Gender Roles Construct: traditionalism and modernity as contents of the desirable model of female gender roles in female magazines in the last quarter of the $20^{\text {th }}$ century" $]$, Filozofija i društvo [Philosophy and Society], no. XIX-XX, 2002, p. 267.

2 Mio Mirković, Ekonomska historija Jugoslavije, [Economic History of Yugoslavia], Zagreb, 1958, p. 352. 
riculture as a main source of income. In an undeveloped, agrarian country, industry was mainly concentrated around towns and mining areas. Instability and prominent differences in the achieved level of economic and political development of some parts and areas in the country were some of the main characteristics of its economic state. Vojvodina apart, which was home to capitalist estates and elements of capitalist agriculture, village life in the rest of Serbia was chiefly marked by bartering and small-scale production of goods. Natural production was characterised by primitive farming methods and the predominance of manual labour in agriculture. Production was primarily geared towards satisfying one's own needs, while families spent the majority of income on their estates, and only a small amount on the market. The predominance of manual labour in agriculture was a result of agrarian over-population and a surplus work force, as well as insufficient technical resources in agriculture. Industry in Serbia was developing, though it was unable to change the pre-war economic structure of the country.

After World War II, the situation was rapidly changed by forced industrialization, which was seen in the socialist country as a basic path and form of society modernization, supported in all possible ways by leaders of the ruling Communist Party, as well as by an accompanying rapid urbanization. Vigorous deagrarianization and the speedy population drain from the village to towns was typical of post-war Serbia and Yugoslavia. ${ }^{3}$

Rural exodus came as the result of global social movements and consequence of an interaction between political and economic factors. It was particularly incited by the policy of industrialization. Industrialization in Yugoslavia, carried out in only several decades, contributed to village population drain and agrarian society transformation. During the second half of the $20^{\text {th }}$ century, a decreasing number of people lived in villages in Serbia and rural areas were less and less inhabited. Many villages were entirely depopulated.

In the changed social and political context, public policy of the socialist country and strategic goals it had formulated were guided by the ideology of its creators. The state in socialism by means of economic policy, methodologically orchestrated economy, state interventionism, legislation, propaganda and in many other ways exerted influence that changed the existing relations in Serbian society, and meddled into people's privacy.

3 Agricultural population accounted for $72.3 \%$ (in Central Serbia $72.4 \%$ ) of the total population of Serbia according to the 1948 census, whereas since 1991, it was reduced to $17.3 \%$ (in Central Serbia to $17.8 \%$ ). Simultaneously, the share of town population in the total number of inhabitants was increased from $22.5 \%$, as it was in Serbia in 1953 (in Central Serbia 21.2\%), to 50.7\% in 1991 (in Central Serbia to $53.6 \%$ ). Changes in the socio-economic structure of the population, according to censuses, Statistički godišnjak Srbije 2006, [Statistical Yearbook of Serbia 2006], Statistical Office of the Republic of Serbia, Belgrade, 2006, p. 75. 
The female population accounted for the majority in Serbia. In 1931 , women accounted for $50.6 \%$ of the total population, in $1948-$ $51.4 \%$, in $1963-51.1 \%$, and in $1961-50.8 \% .{ }^{4}$ Such a trend continued. In 1991, there were 104 women per 100 men, and in 2002, 106. ${ }^{5}$

The daily life of a woman in the recent history of the Serbian society can be observed at several levels and in different dimensions. Woman's life in socialism was determined and affected by a multitude of factors. Parallel images of woman's everyday life were diverse, differing in many segments.

The modernization of society implied the promotion of a different character and identity of a woman, and supported her emancipation. The idea of woman's importance and function in the society was changed. ${ }^{6}$

\section{State policy and the creation of woman's identity in socialism}

A favourable legal framework directed towards gender equality was part of the general social context. A series of laws and directives of different legal stature adopted immediately after the liberation of the country followed in the years to come an ideological proclamation of the party state on the equality of men and women in all segments of life. The foundations of legal equality and the elimination of inequality between man and woman imbedded in law, as a precondition for general women's emancipation, were established in the period of an early socialist state. Attempts to modernize society, perceived through the progress achieved in regard to female population's emancipation, can be noticed primarily in normative regulations of the party state.

The egalitarianism between man and woman, proclaimed by the socialist order at the level of principle, was promoted from the very beginning as the stronghold of entire modernization of society. The equality in inheritance and family law, political rights (active and passive voting rights), the right of work and an equal pay for equal work, rights in the domain of social protection, right to abortion, etc., represent women's achievements that are here related to the socialist authority.

4 Žena u društvu i privredi Jugoslavije, Statistički bilten, 298, [Woman in Society and Economy of Yugoslavia, Statistical Bulletin no. 298] Belgrade, 1964, p. 10.

5 Žene i muškarci u Srbiji, [Women and Men in Serbia], Statistical Office of the Republic of Serbia, United Nations Development Programme, Belgrade, 2005, pp. 10,11

6 Vera Gudac Dodić, „Prostor kao sudbina: život ženskog stanovništva u gradskim i seoskim naseljima u Srbiji tokom druge polovine 20. veka" [Living Area as Fate or Destiny: Life of Female Population in Rural and Urban Areas of Serbia in the Second Half of the 20th Century] Istorija i geografija: susreti i prožimanja, ed. Sofija Božić, pp. 375-386. 
Women were granted different roles compared to the ones they had had in the previous regime, the roles of working heroines, equal and present everywhere. Such roles were supported by the socialist state and permeated with legislation and changes at the level of women's political and other rights. The socialist society was not short of laws and normative acts which guaranteed gender equality. However, in spite of numerous emancipation and modernization measures taken by the socialist authority in that sphere, the equality of man and woman was more based on the party state's decrees than on the essential changes of relations in daily life.

Compared to the previous legal practice in Serbia and the existing laws which had been in force before World War II, essential changes were made in the field of the legal position of married women and the regulation of marital and family relations. Women's inequality was particularly reflected in the business capacity of a married woman in those parts of Serbia in which the Serbian Civil Code ${ }^{7}$ had been in force since 1844. A married woman was equal in terms of her general business capacity with minors, insane persons, squanderers and derelicts. Her legal position was such that she was completely subordinated to her husband. In case of divorce, male children older than four or girls older than seven would always belong to father, etc. Determining and establishing paternity of an illegitimate child was prohibited, except in case of abduction or rape. ${ }^{8}$ By means of the Basic Marriage Law ${ }^{9}$ all state regulations on marriage that had been valid up to then were abolished and changed. Constitutional and legal provisions changed the legal position of a married woman and liberated her from male predominance before the law. The Serbian Civil Code, as a legal base of both the woman's discrimination in marriage and patriarchal family, was no longer valid. ${ }^{10}$

Inheritance law was a significant stronghold of gender inequality. Based on normative regulations, woman's inequality in terms of inheritance in pre-war Serbia was an integral part of daily life. The discrimination of women in terms of inheritance was manifested in the way that inheritance was granted to male children, i.e. to maleline descendants. Female children appeared as heirs only when there

7 Građanski zakonik Kraljevine Srbije, [Civil Code of the Kingdom of Serbia], Belgrade, 1913.

8 Marija Draškić, Olga Popović-Obradović, „Pravni položaj žene prema Srpskom građanskom zakoniku (1844-1946)", [Legal Position of a Woman According to the Serbian Civil Code (1844-1946)], Srbija u modernizacijskim procesima 19. $i$ 20. veka, 2, Položaj žene kao merilo modernizacije, [Serbia in the Modernization Processes of the $19^{\text {th }}$ and $20^{\text {th }}$ Century, 2, Position of a Woman as Criteria of Modernization], ed. Latinka Perović, Belgrade, 1998, pp. 11-26.

9 Osnovni zakon o braku, Službeni list FNRJ, [Basic Law on Marriage] [Official Gazette of the FPRY], 1946.

10 The adoption of the Law on the invalidity of legal regulations established before April 6, 1941, and during the enemy occupation, contributed to the Serbian Civil Code expiration. Draškić, Popović-Obradović, Ibid, p. 12. 
were no male descendants. Inheritance right inequality was particularly noticeable in those parts of Serbia in which the Serbian Civil Code was in force. Widows were entitled to a so-called widow's enjoyment, i.e. the right to enjoy husband's inheritance. The privileged status of men and the prominent discrimination of women, which was particularly expressed in the inheritance law, were abolished by the Law on Inheritance passed in 1955 . The Law guaranteed inheritance equality between men and women and made them equal. ${ }^{11}$

Deprived of their rights in the political sphere, women were granted voting rights in 1945, while the first post-war Constitution from 1946 guaranteed their equality with men in all fields of state, economic and socio-political life. ${ }^{12}$

The liberalization of divorce, achieved after the war, was followed by some adequate legal solutions. Except for the property owned by a spouse at the time of concluding marriage, and the property a spouse received as a gift or inherited during the marriage, all the property acquired in marriage was considered common property. In case of divorce, spouses would share their common property in accordance with their individual contributions. ${ }^{13}$

The possibility of free education and schooling, which was open and available to women, resulted in women's increasing school attendance at all educational levels. By their presence in academic educational institutions, women gradually became equal to men, starting from primary schools to universities. The discrepancies typical for the period immediately after World War II gradually disappeared.

The socialist state encountered enormous illiteracy of its population, there were differences in the level of literacy in some areas and parts of Serbia, between towns and villages and between male and female population. The greatest stronghold of illiteracy was the village, particularly its female inhabitants. ${ }^{14}$ Immediately after the liberation numerous educational courses were organised, broadly involving women. Female students attending adult literacy courses often came from villages (70\%). Although organised on a massive scale, the courses for illiterates did not cover all illiterate persons.

11 Ibid, pp. 19-21.

12 Ustav FNRJ, Službeni list FNR] 1946, [Constitution of the FPRY] [Official Gazette of the FPRY], Chapter 5, Rights and obligations of citizens, Article 24, p. 77.

13 Osnovni zakon o braku, [Basic Law on Marriage], 1946. The Basic Law on Marriage was further developed by additionally adopted republic regulations. Legal solutions from the time of an early communist state protected the institution of marriage "to greater extent" than later legislature. The total liberalization of divorce and proceedings for marriage termination were realized by clauses of the Law on Marriage and Family Relations. Zakon o braku i porodičnim odnosima, Službeni glasnik SRS, br. 22/80, [Law on Marriage and Family Relations] [Official Gazette of SRS no. 22/80].

14 There were prominent differences in the level of female literacy in some parts of Serbia. The smallest percent of illiterate women was on the territory of Vojvodina and the greatest in Kosovo. 
At the end of the $20^{\text {th }}$ century, the majority of the illiterate in Serbia was among older women. Illiteracy of the female population in Serbia was not eradicated but was considerably reduced during the socialist period

Many girls did not finish primary school. ${ }^{15}$ Those girls who lived in poor and mountain areas frequently did not attend school, despite regulations on obligatory primary school attendance. ${ }^{16}$ Parents in villages sometimes resisted the literacy courses and schooling of their female children, as they regarded it not necessary for field and domestic work, i.e. for the roles they were intended for.

In order to neutralize conservative stances and perceptions of women, the party state attempted to find different forms of activity it could act through, at first via the women's organisation AFŽ, directed towards an increase in women's literacy and education level. Its work was based on educating women and female children. ${ }^{17}$

In spite of insufficient schooling, education was a segment of life in which women generally made great progress in the second half of the $20^{\text {th }}$ century in comparison to the previous periods and generations. Therefore, girls from villages were directed, more than before, towards different levels of schooling. This resulted in girls leaving their parents' homes for small provincial towns and cities, and most frequently leaving the villages for good.

Rights granted to and won by women influenced their daily life, as well. However, another question is to what extent the acquired women's rights could contribute to the overcoming and neutralizing the patriarchal system of values, which was incorporated into tradition, culture and customs, and could define gender roles in different manner.

Socialist practices were not the same during the entire existence of the party state in Yugoslavia and Serbia, and its various developmental phases and social changes were reflected on woman's daily life as well. A new image of a woman in socialism was created, which was typical for the Communist Party ideals and spirit of the time, new rights and duties were established, norms opposing patriarchy and the practice of social inequality in gender relations. were promoted.

At the second congress of Women's Antifascist Front of Yugoslavia (AFŽ), ${ }^{18}$ in 1948, Mitra Mitrović formulated an ideal woman,

$15 \mathrm{AJ}, 142$, 468, Federation of Cooperatives of Yugoslavia, Belgrade, April 3, 1980.

16 The strengthening and spread of school network in the post-war period, a constant rise in the percent of girls attending primary school which gradually became equal to boys, an increasing coverage of children, were the main characteristics of primary schooling in Serbia.

17 Despite laws, literacy teaching activities, strong state propaganda, illiteracy still survived, particularly in the villages.

18 Women's Antifascist Front of Yugoslavia, AFŽ, was a mass socio-political organisation of women during the war, established in 1942 and abolished in 1953. 
which was affirmed at the time by the Communist Party of Yugoslavia: "The most beautiful traits of a Yugoslav women have been and are being discovered in their massive participation both in war and in the establishment of free and independent country. Today, the mentioned traits from which the new image of a new woman evolves should be further molded and cherished in the spirit of a conscious relation towards her own work... in the spirit of work discipline and responsibility, in the spirit of readiness to make efforts to overcome all difficulties that are to be overcome in these years of an all-round rebuilding of the country, in the spirit of the fight against dispiritedness and difficulties, against old prejudices which make women passive and have a harmful effect on the rapid building of the country. Out of those characteristics, the new image of a woman, similar to that of our war heroes, grows in the creation of socialism" 19 .

In the first years after liberation, the ideal of a strong woman, fighter, "comrade", who surpasses all work norms by outstanding devotion, who becomes an activist, shock worker and a work heroine" was favored. Muscled as the result of a shovel and a hoe, a shock-worker of work brigades shows by her monumental feminine nature (resilient women from Augustinčić and Rosandić's sculptures) the strength and fertility that was so needed for social-economic recovery." 20 Such an image was the paradigm of a woman in socialism. "Post revolutionary discourses on shock workers introduced work as a duty towards Society, Socialism and Future, encouraging enthusiasm for work and individual endeavors to fantastic proportions". ${ }^{21}$ In the early 1950s, outlines of a different trend appeared, lifestyle was slightly changed and such a soc-realist ideal was gradually abandoned.

The media were powerful promoters with regard to the formation of the desirable image of a woman in socialism and they made an impact on the molding of social norms, values and stances on gender roles. Regardless of particular women's themes and attributes it introduced, the presentation of a woman in the press, in times of the early socialist state, reflected state ideology, i.e. the ruling Communist Party's stances and ideological background they were based on.

In 1953, the Union of Women's Societies of Yugoslavia was set up, and in 1961, it was reorganised and followed by the foundation of the Conference for the Social Activity of Women in Yugoslavia, which acted under the auspices of the Socialist Alliance of Working People of Yugoslavia.

19 Govor Mitre Mitrović na Drugom kongresu AFŽ-a Jugoslavije, Politika, 26. 1. 1948. [Speech of Mitra Mitrović at the Second Congress of AFŽ of Yugoslavia, Politika, January 26, 1948]

20 Neda Todorović-Uzelac, Ženska štampa i kultura ženstvenosti, [Female Press and the Culture of Feminity], Belgrade, 1987, p. 133.

21 Danijela Velimirović, "One su bile svuda, stizale su sve: kulturna konstrukcija heroina novog doba 1945-1951" [They Were Everywhere - They Got Everything Done: The Cultural Construction of the Heroines of the New Age (1945-1951),] Etnoantropoloski problemi, 2012, br. 7, [Ethno-anthropological Problems, 1912, no. 7], p. 176. 
The presentation of a woman in the socialist press emphasized her legal, economic and social equality, and it supported various female roles, such as shock workers, brigadiers, workers, mothers, members of cooperatives. ${ }^{22}$ Thus, the model or ideal image of a woman in socialism was formed and imposed. As of the 1950s, the idea of woman's identity in the press gradually covered other aspects, as well. Articles were gradually and discretely appearing after the war, stressing and reviving the abandoned cult of woman's beauty and fashion trends, and opening up "typical" women's topics.

Goals posed before women by the socialist authority depended on many agents, numerous economic and ideological factors, as well as different political circumstances. Attempts of the party state to influence the creation of the socially desirable function of a woman in post-war Yugoslavia were made, inter alia, through Josip Broz Tito's papers, public appearances and speeches. They reflect global issues significant for society and current events that marked certain stages in the development of socialist Yugoslavia and Serbia. Tito's addresses intended for women were based on particularities that characterized each of those stages and were part of the social affirmation of concrete party goals. Josip Broz's speeches in which he addressed women represent a significant record and testimony of his policy, the manifestation of its influence on the creation of the social identity of a woman in socialism. Messages in Tito's speeches were of primarily ideological and political nature, whether he addressed women directly or the Women's Antifascist Front, the organization they were represented by.

Promotion of the concept of a comrade-workwoman in Josip Broz's public appearances and speeches was a way of creating woman's identity in socialism and a stronghold of her social role's formulation. In the period up to the final liberation of the state, the issues of women's war activity were dominant in his speeches as various actions aimed at helping fighters in battlefields, the wounded, orphans, etc. The first five-year plan period abounded in speeches and texts published in the press on the participation of women in state economic life, their activities regarding the fulfillment of the Plan, as well as in criticisms of those who stood by and refused to be part of such a state mechanism. All of his addresses to women were permeated with the affirmation of diligent and socially engaged women, praise of work and work enthusiasm, as well as with the stimulation of a

22 Vera Gudac Dodić, "Analiza tekstova o ženi u listu Politika 1945-1953", [Analysis of texts about woman in Politika daily 1945-1953], Srbija u modernizacijskim procesima 19. i 20. veka, 2, [Serbia in the Modernization Processes of the $19^{\text {th }}$ and 20 $0^{\text {th }}$ Century, 2: Position of Woman as Criteria of Modernization] pp. 394407; Gordana Stojaković, "Antifašistički front žena Jugoslavije (AFŽ) 1946-1953: pogled kroz štampu", ["Women's Antifascist Front of Yugoslavia (AFŽ) 19461953: through the press"], Rod i levica [Gender and the Left Wing], Belgrade, 2012, pp. 13-39. 
competitive spirit. A prominent break-through on the subject of the conflict with Informbiro into all segments of society pervaded interviews and reports directed towards female population, as well. ${ }^{23}$ Josip Broz's speeches dealing with the role of women and an accompanying media echo were actually a request and invitation for the mobilization of women for a variety of activities and tasks both imposed on them by the socialist state and expected of them by the society. ${ }^{24}$

Public activities, women's voluntary work in hospitals, in fields during harvests, in volunteer work brigades, were the practice of socialism in its early stage. ${ }^{25}$ Social life dominated over the individual one. The domains of private and public were not entirely demarcated, while individual's daily life was marked with the party state's interference into all segments of life and spheres of privacy. The first post-war years promoted the idea of working for the benefit of all, by presenting interests of the socialist state as general ones. The idea of working not only for one's own interests but also for "public good" shaped everyday social life. "Nobody shall consider that he has given their best for a community, if he is still physically and mentally able to work", Tito used to tell women. "Having said this, I do not think of women burdened with care for their children, as that is social work as well." 26 Woman's identity in socialism was formulated primarily through maternity and through work. Other coordinates used for defining an ideal woman were the participation in national power, i.e. political activism and illiteracy eradication.

Great attention was paid to issues and problems regarding maternity, which were considered as the key ones. An idea of child upbringing under the control of the socialist state and under the auspices of its ideology was present everywhere. As written down in documents of the time, the state took care of young generations, protected maternity and made efforts to replace family influence and to bring up children in accordance with the promoted values, in a way that will remove "the negative influence of domestic upbringing, in

23 Govor J. B. Tita na Trećem kongresu Antifašističkog fronta žena, [Speech of J. B. Tito at the Third Congress of Women's Antifascist Front], Josip Broz Tito, book 5, Borba za socijalističku demokratiju, [Struggle for Socialist Democracy] (Culture, 1955) pp. 43-64.

24 Vera Gudac Dodić, "Između javnog i privatnog: Tito o svakodnevici žena u socijalizmu" [Between the Public and Private: Tito on Women's Everyday Life in Socialism] Tito - viđenja i tumačenja, [Tito - Views and Interpretations], ed. Olga Manojlović Pintar, Belgrade, 2011, pp. 360-371.

25 In 1947, women in Serbia spent $6,748,151$ of working hours on voluntary work, and in 1949, women in Vojvodina reached the amount of around 14,000,000 working hours.

26 Arhiv Jugoslavije, [Archive of Yugoslavia] (AJ), 836, Kancelarija maršala Jugoslavije (Office of the Yugoslav Marshal) II-3/f -1-1, Govor Josipa Broza Tita na Drugom kongresu AFŽ-a, 1948. [Speech of Josip Broz Tito at the Second Congress of AFŽ, 1948]. 
case it is negative". ${ }^{27}$ Socialist authorities did not consider maternity as an entirely private matter in women's life, and they interfered in many ways, both directly or indirectly, in their privacy, trying to gain control and protective influence over children and young people. The transfer of family's pedagogical role to the society and its institutions is a pronounced and obvious breakthrough of the public into the private. In talks with delegations and women's representatives and in his public appearances, Josip Broz used to emphasize that one of the most significant tasks is the upbringing of children in line with values and ideals of the socialist society. "It is of great importance for us that children be correctly brought up in the spirit of new Yugoslavia. Do not allow enemies of new Yugoslavia to poison and alienate our children. Take care of and keep a vigil over our children in order for them to really become worthy citizens of our new Yugoslavia, citizens of the new country of socialism. That is one of your most important tasks ".28

The right to work was one of the central points of woman's emancipation, while women's employment was in accordance with the expected social roles they were assigned. The idea of women's economic independence as the main precondition of emancipation, at least at the level of abstract principles, was part of the left-wing ideology the system in Yugoslavia was based on. The employment of women was one of the popularized segments of social life, the principle of equal pay for equal work was implemented in normative regulations, and the tendency towards diminishing the existing differentiation between male and female professions was an official stance. Although some texts in the AFŽ documentation, and not only there, point to a discrepancy between the proclaimed policy of gender egalitarianism on the labour market and sometimes contrary practice, women in Serbia and Yugoslavia were increasingly employed. After strong women's breakthrough into the economic life of the country just after the war and in the restoration period, there was a tendency in the early 1950s towards a decrease in the percentage of employed women compared to the total number of employed people. Vida Tomšić, President of AFŽ, warned at its IV and the last congress of the appearance of "some new, quasi democratic theories about woman and family that practically had a negative influence primarily on the issue of woman's economic independence". In some firms, female labor is considered as "less profitable", while the introduction of relatively high child benefit is often misunderstood, as if "the time has come that female labor is not needed any more and that it is on the path of retreating from business toward household, with its

27 Istorijski arhiv Beograda, [Historical Archives of Belgrade], (IAB) Town Conference of SSRNJ, Belgrade, Conference for the Social Activity of Women, k. $1, \ldots$ Programme of Work of the Mother-Child Section for 1949.

28 AJ, 836, KMJ-II-3/f-1-1, Govor Josipa Broza Tita na Drugom kongresu AFŽ-a, 1948 [Speech of Josip Broz Tito at the Second Congress of AFŽ, 1948]. 
natural, exclusive duty of being a housewife, mother and governess of her own children".29

Since the mid-1950s, the number of women working outside their homes increased ${ }^{30}$, although they constantly presented the majority of unemployed population. Women were being widely employed despite some restrictions that sporadically appeared in practice.

A paradox between the existing and projected paradigmatic image of a woman after the war and in the decades to come even more complicated an ambivalence of the socially desirable and expected roles of women, in other words the ambivalence within the very idea of a woman in socialism. ${ }^{31}$

Daily life of employed women, spouses and mothers brought to the foreground their conflicting roles and the issue of their harmonization. The double burden became a leitmotif of a woman's life. The reduction of a woman's free time up to the utter limit regardless of acquired rights and attained freedoms pointed again to an unequal treatment of men and women. ${ }^{32}$

An image of women's daily life in the socialist state showed that women's legal equality and economic independence was not sufficient for their full gender equality. Even in the altered political circumstances, women did almost all household chores, childrearing and other work connected with family life. Domestic work was based on the engagement of women who were also employed outside their homes and thus carried the greatest burden. Changes in the social and political life did not entail the transformation of relations in the sphere of women's personal life, at least when it comes to domestic labor. Gender inequality still shaped the family's daily life. The issue of unburdening employed women did not only belong to the field of activity and engagement of women's organizations, but it was also a general social issue. "The question of real implementation of woman's equality and her active participation in social and public life is closely related to the issue of unburdening her from household tasks". 33

The strategy of Yugoslavia, ever since the establishment of the socialist state, adhered to the same principles in this regard and had particular features. At the level of theoretical orientation, policy makers pursued a clear direction: domestic work should be socialized. At

29 Research paper of Vida Tomšić at the IV Congress of the AFŽ of Yugoslavia, Politika daily, September $27^{\text {th }}, 1953$.

30 The greatest percentage of the unemployed was in Kosovo and the smallest in Slovenia. Dragana Stjepanović Zaharijevski, Moć i nemoć žene, [Power and Weakness of a Woman] (Niš, 1999) p. 125.

31 Historian Lydia Sklevicky was the first one to examine the combinations of women's roles resulting from contradictory requirements, "their traditional and newly acquired social and cultural roles". Renata Jambrešić Kirin, Dom i svijet, [Home and World], Centre for Women's Studies, Zagreb, 2008, p. 28.

32 Gudac Dodić, "Između javnog i privatnog: Tito o svakodnevici žena u socijalizmu", [Between the Public and Private: Tito on Women's Daily Life in Socialism], p. 366.

33 AJ, 117-236, Domaćinstvo [Household]. 
the fourth plenum of the Central Committee of AFŽ Yugoslavia in the early 1950s, it was emphasized in the conclusions that "... running a household shall be turned into a social industry, which will liberate women from a significant amount of domestic labor, enable them to pursue the broadest possible social activity and create material conditions needed for greater and freer development of a family".,34 In the following years, there were no significant changes in the state policy. Two and a half decades later, such orientation was still dominant and formulated in "Yugoslav Strategy for Women's Development Integration": "An exercise of equal rights in the society is countered by the practice of maintaining old divisions of labor, old unequal domestic and family obligations. The idea of solving the conflict between these two spheres is neither based on the equal distribution of obligations to all household members, nor is it possible to accept the division of woman's lifespan into three periods, education, maternity and work, as recommended. The main path is to turn the majority of those activities into public social work branches. Economic and social processes are already moving in that direction, supported by the modern development of production forces, science and technology." 35

The socialist concept did not formulate the involvement of men into domestic activities, but the socialization of domestic work and family obligations. ${ }^{36}$ The idea of domestic work socialization did not suggest that all family functions be taken over by the state, but only some of them that were traditionally performed in the household.

Attempts made by the state to primarily decrease the double burden carried by employed women practically moved into two directions. One of them was the socialization of household tasks in different ways, primarily through the establishment of services. It was planned that services be established either within house councils or residential communities. ${ }^{37}$

Another segment referred to the modernization of the domestic work by using modern home appliances and contemporary technical achievements, which had already appeared in the world. It was necessary to increase both domestic production of home appliances and their import.

Domestic work was often carried out in a primitive way, primarily in rural environments. It was usually done manually, thus demanding a lot of time and energy. The AFŽ and the Union of Women's Societies, and later the Commission for Women within the Socialist

34 AJ, KPR II-2-16, box 39.

35 AJ, KPR II-3-F, box 161. Deseti međunarodni seminar Konferencije za pitanja društvenog položaja žena Jugoslavije, [The $10^{\text {th }}$ International Seminar of the Conference for the Social Position of Women in Yugoslavia], Ljubljana, 1977.

36 Davor Topolčić, "Muškarci to ne rade: rodno segregirana podjela rada u obitelji", [Men Don't Do That: Gender Segregation of Domestic Division of Labour], Društvena istraživanja, br. 4-5, [Social Researches, no. 4-5], Zagreb 2001, p. 771.

37 AJ, 117-236. 
Alliance, made great efforts to encourage all authorities and social organizations to enable more modern running of a household and decrease the burden of employed women regarding domestic chores. Apart from the modernization of domestic work by using modern machines and appliances on one hand, and the externalization of domestic tasks by organizing communal feeding, establishing various communal institutions for family assistance, services, etc. on the other hand, the mentioned activities included the education of housewives and women's enlightenment.

Numerous institutions and establishments all over the country were engaged in the promotion of the household. Speaking of Serbia, there were: an institute within the Federal Institute for Work Productivity in Belgrade, the Institute for the Promotion of Domestic Science of the PR Serbia, and centers for the promotion of household. Specialized schools were opened, as well. People working in the mentioned institutes were engaged in research regarding healthy diet, practical apartment arrangement, modern dressing, domestic science, home economics, as well as in the organization of seminars, courses, lectures and publishing brochures, magazines and popular publications of their research. ${ }^{38}$

Modernization activities and strong, real achievements of the policy of emancipation with regard to women, which were manifested in numerous spheres of life, primarily in the domain of formal and legal relations between genders and mass schooling and employment of women, did not lead to the change in traditional family roles. As one of the generators of gender inequality, they contributed to the conflict of employed woman's roles.

Real-socialism emphasized political and economic liberation of women on the one hand, and "integrated a patriarchal bourgeois family in its idealized form" 39 on the other. Women in socialism, therefore, lived in two separate worlds, at their work places and other forms of public activities, and "in the private family world of bourgeois idyll in the afternoon or evening. A woman in socialism was the symptom of its discrepancy in the full sense." 40 According to contemporary feminist culturological analyses, in spite of legal support, an undisturbed access to free education and social protection that the socialist regime provided to women, thus offering them such a short-term development as no other political system, the Party disabled women, "with its usurpation of power and supervision over the entire social field", to develop their own "political skills necessary for defending and expanding personal rights." ${ }^{41}$

$38 \mathrm{AJ}, 117-236$.

39 Anđelka Milić, "Socijalizam i feminizam - spojevi i razilaženja" ["Socialism and Feminism - Connections and Discrepancies"], Rod i levica [Gender and the Left Wing], Belgrade, 2012, p. 43.

40 Milić, "Socialism and Feminism - Connections and Discrepancies", p. 43.

41 Kirin, Home and World, p. 23. 
Social awareness, i.e. some of its forms such as ideology, law, politics, etc. reflected on gender relations and had an influence, apart from other factors, on the construction of women's identity in socialism and initiated changes of the idea of woman. The emancipatory character of the socialist state neither reflected entirely on gender equality, nor was it supported to the utmost by vigorous but incomplete modernization of the society. "Although the idea of equality was ubiquitous, it did not manage to overcome the traditional concept of life ". ${ }^{42}$ Although they publicly propagated the idea of gender equality, Yugoslav ideologists did not succeeded in making a radical break with the cultural forms of pre-revolutionary society which were based on "the idea of gender differences and compatibility". ${ }^{43}$

Political and other changes in social circumstances resulted in the construction of woman's identity in a different way. For the Communist Party, molding and constructing the image of an ideal woman during the war, in times when female fighters and activists appeared on the social scene, obtained a prominently ideological content. Transformation of the typical image of a woman immediately after the war and in times of rebuilding the country brought work heroines to the foreground, thus changing the idea of femininity and discarding typical female attributes. The concept of female comrade was promoted in all possible ways. Efforts of the state and activities of the Communist Party and women's organizations aimed at eradicating illiteracy that was very pronounced among female population at that time also shaped and depicted the desirable image of a woman, while woman's education and schooling became an important part of her collective identity. The Soc-realistic ideal of a woman as a worker and mother acquired different outlines in time, so in the early 1950s the after the war forgotten femininity was revived in various ways. In the context of socialism, work and maternity were strongholds for defining an ideal image and for the social construction of woman's identity.

42 Karl Kazer, Porodica i srodstvo na Balkanu: Analiza jedne kulture koja nestaje, [Family and Relationship in the Balkans: Analysis of a Vanishing Culture], Belgrade, 2002, p. 448.

43 Kirin, Home and World, p. 20. 


\section{Резиме}

Др Вера Гудац Додић

\section{Политика државе и идентитет жене у социјализму}

Кључне речи: идентитет, улоге, жена, идеални лик, социјализам

Процеси креирања женских идентитета кроз конструкцију идеалног лика жене у социјалистичкој Србији и Југославији били су усмеравани политиком државе, прожети идеологијом социјализма и комунизма и делом зависни од активности Комунистичке партије. Партијска држава је на различите начине утицала на формулисање и обликовање друштвено пожељне функције жене у послератној Југославији, поред осталог, јавним наступима државних и комунистичких лидера, социјалистичком штампом, представљањем жене у њој и др. Конструисан је нови лик жене својствен идеалима Комунистичке партије и духу времена, утемељена су нова права и дужности, промовисане другачије друштвене и културне улоге жене. Модернизацијски помаци и реални учинци еманципаторске политике према жени манифестовали су се у многим сферама живота, пре свега у домену формално-правних односа међу половима, те масовном школовању и запошљавању жена, али нису довели до промена традиционалних улога у породици. Оне су биле један од генератора родне неједнакости и доприносиле конфликтности улога запослене жене. У контексту социјализма рад и материнство били су упоришне тачке у дефинисању идеалне слике и друштвеној конструкцији идентитета жене. 